\title{
Growth, survival, and peptidolytic activity of Lactobacillus plantarum 191 in a hard-cheese model
}

\author{
C. V. Bergamini, ${ }^{* 1}$ G. H. Peralta, ${ }^{*}$ M. M. Milesi, ${ }^{*}$ and E. R. Hynes ${ }^{*} \dagger$ \\ *Instituto de Lactología Industrial, Universidad Nacional del Litoral - Consejo Nacional de Investigaciones Científicas y Técnicas, \\ Santiago del Estero 2829, S3000AOM Santa Fe, Argentina \\ †Facultad de Ingeniería Química, Universidad Nacional del Litoral, Santiago del Estero 2829, S3000AOM Santa Fe, Argentina
}

\begin{abstract}
In this work, we studied the growth, survival, and peptidolytic activity of Lactobacillus plantarum I91 in a hard-cheese model consisting of a sterile extract of Reggianito cheese. To assess the influence of the primary starter and initial proteolysis level on these parameters, we prepared the extracts with cheeses that were produced using 2 different starter strains of Lactobacillus helveticus 138 or 209 (Lh138 or Lh209) at 3 ripening times: 3, 90, and $180 \mathrm{~d}$. The experimental extracts were inoculated with $L b$. plantarum I91; the control extracts were not inoculated and the blank extracts were heattreated to inactivate enzymes and were not inoculated. All extracts were incubated at $34^{\circ} \mathrm{C}$ for $21 \mathrm{~d}$, and then the $\mathrm{pH}$, microbiological counts, and proteolysis profiles were determined. The basal proteolysis profiles in the extracts of young cheeses made with either strain tested were similar, but many differences between the proteolysis profiles of the extracts of the Lh138 and Lh209 cheeses were found when riper cheeses were used. The $\mathrm{pH}$ values in the blank and control extracts did not change, and no microbial growth was detected. In contrast, the $\mathrm{pH}$ value in experimental extracts decreased, and this decrease was more pronounced in extracts obtained from either of the young cheeses and from the Lh209 cheese at any stage of ripening. Lactobacillus plantarum I91 grew up to $8 \mathrm{log}$ during the first days of incubation in all of the extracts, but then the number of viable cells decreased, the extent of which depended on the starter strain and the age of the cheese used for the extract. The decrease in the counts of $L b$. plantarum I91 was observed mainly in the extracts in which the $\mathrm{pH}$ had diminished the most. In addition, the extracts that best supported the viability of $L b$. plantarum I91 during incubation had the highest free amino acids content. The effect of $L b$. plantarum I91 on the proteolysis profile of the extracts was marginal. Significant changes in the content of free amino acids
\end{abstract}

Received January 11, 2013.

Accepted May 25, 2013.

${ }^{1}$ Corresponding author: cvberg@fiq.unl.edu.ar suggested that the catabolism of free amino acids by $L b$. plantarum I91 prevailed in a weakly proteolyzed medium, whereas the release of amino acids due to peptidolysis overcame their catabolism in a medium with high levels of free amino acids. Lactobacillus plantarum I91 was able to use energy sources other than lactose to support its growth because equivalent numbers of cells were observed in extracts containing residual amounts of lactose and in lactose-depleted extracts. The contribution of $L b$. plantarum 191 to hard-cooked cheese peptidolysis was negligible compared with that of the starter strain; however, its ability to transform amino acids is a promising feature of this strain.

Key words: Lactobacillus plantarum, sterile cheese extract, hard-cooked cheese, proteolysis

\section{INTRODUCTION}

The heterogeneity and dynamics of the nonstarter lactic acid bacteria (NSLAB) population depend on the availability of nutrients and the environmental conditions of a cheese, which change during ripening (Lane et al., 1997; Williams et al., 2000; Beresford, 2003). For this reason, it has been proposed that those species or strains able to metabolize the nutrients that are available initially will predominate at the beginning of the ripening process. However, this population's growth rate declines when these substrates are exhausted, and then the population of different species or strains capable of metabolizing the substrates that had been produced during ripening will increase (Fitzsimons et al., 2001; Williams et al., 2002; Beresford, 2003). In general, Lactobacillus plantarum is the species typically found in cheese at the beginning of the ripening process, whereas Lactobacillus casei predominates in mature cheese, although few studies have addressed this subject in detail (Litopoulou-Tzanetaki, 1990; Fitzsimons et al., 2001; Mangia et al., 2008).

The energy source for the growth and maintenance of viability of NSLAB in cheese has not been clearly elucidated (Budinich et al., 2011; Moe et al., 2012). It is believed that NSLAB begin their growth in cheese at the expense of the residual lactose (Williams et al., 2000). 
However, the amount of residual fermentable carbohydrates in cheese - mainly lactose and galactose - is very low, and other energy sources are necessarily involved in NSLAB growth and viability (Beresford, 2007). Many strains of NSLAB origin are able to catabolize or grow on nitrogen-containing compounds of medium and small size, although it is still matter of controversy whether they can use amino acids or oligopeptides as sources of energy (Tammam et al., 2000; Williams et al., 2000; Laht et al., 2002; Brandsma et al., 2012). In addition, the amount and identity of amino acids and di- and tripeptides in cheese changes during ripening and from one cheese type to another as a consequence of the evolution of proteolysis (Upadhyay et al., 2004).

Early studies reported that autolytic starters were favorable for the growth of NSLAB because their cellular contents could provide the NSLAB with carbohydrates (Thomas, 1987), and their intracellular enzymes increased the pool of peptides and amino acids (Kiernan et al., 2000; Hannon et al., 2003; Kenny et al., 2006). However, similar levels of NSLAB have been reported in cheeses manufactured with lytic and non-lytic starters (Lane et al., 1997; Hynes et al., 2001). A more recent study proposed that highly proteolytic primary starters, rather than autolytic starters, stimulate the growth and peptidolytic activity of mesophilic lactobacilli. However, this synergic effect depends of the genus, species, and strain of the lactic acid bacteria chosen as the starter (Lane et al., 1997; Hynes et al., 2001; Di Cagno et al., 2003). Research that addressed the interactions between the NSLAB and the primary starter almost exclusively concerned the mesophilic lactic acid bacteria (i.e., Lactococcus spp.). Little is known about the influence of thermophilic starters, such as Streptococcus thermophilus and Lactobacillus helveticus, on the growth and biochemical activities of the NSLAB. However, these species are widely used worldwide as starter cultures to obtain valuable cheeses. In Argentina, thermophilic lactic cultures are the main lactic cultures; to produce Reggianito cheese, a natural whey starter culture containing Lactobacillus helveticus, or commercially available strains of the same species, is applied (Reinheimer et al., 1995, 1996; Hynes et al., 2003; Vélez et al., 2010). Overall, Lb. helveticus is a strongly proteolytic species compared with other lactic acid bacteria, but this ability varies highly both in intensity and specificity from one strain to another (Oberg et al., 2002; Jensen et al., 2009). Cheeses produced with different strains of $L b$. helveticus can show very different extents and profiles of proteolysis, characterized by different proportions of middle-sized and small peptides as well as the individual free amino acids (Chopard et al., 2001; Hynes et al., 2003; Hannon et al., 2007).
The performance of individual strains of lactic acid bacteria on cheesemaking and ripening both as starter and adjunct cultures is usually assessed by cheesemaking trials, which are both time-consuming and expensive. Some biochemical events, such as those resulting from pairing starter and adjunct cultures, may be masked by a highly complex background of milk compounds and their many metabolites. To cope with these difficulties, cheese models have been proposed, such as cheese slurries, Ch-easy, miniature cheeses, and soluble extracts (Farkye et al., 1995; Smit et al., 1995; ShakeelUr-Rehman et al., 1998; Hynes et al., 2000; Crow et al., 2001; Hynes et al., 2004; Budinich et al., 2011). Cheese models are simplified, reproducible and reliable ecosystems that require shorter times for preparation and ripening than do standard cheesemaking trials; they also allow the production of more replicates. In a previous study, we showed that an aqueous cheese extract was appropriate to model the ripening of hard-cooked cheese in short periods of time (Milesi et al., 2011). The objective of the present work was to assess the influence of the primary starter strain and the age of the cheese made with it on the growth, survival, and peptidolytic activity of $L b$. plantarum I91, in a model prepared from a filter-sterilized soluble extract of a hard cheese type: Reggianito.

\section{MATERIALS AND METHODS}

\section{Cultures}

Lactobacillus helveticus 138 and 209 (Lh138 and Lh209) were obtained from the collection of the Instituto de Lactología Industrial (INLAIN, Santa Fe, Argentina). They were isolated from natural whey cultures from 2 different dairy plants and showed different proteolytic activities in vitro and in cheesemaking experiments (Quiberoni et al., 1998; Candioti et al., 2002).

Lactobacillus plantarum I91 was obtained from the NSLAB collection of INLAIN; it was isolated from a good-quality 2-mo-old Tybo Argentino cheese produced in an industrial environment (Ugarte et al., 2006). The influence of this strain on the ripening and sensory characteristics of soft, semi-hard, and Cheddar cheeses was previously investigated using miniature models (Milesi et al., 2008) and at pilot-plant scale (Milesi et al., 2009).

Stock cultures of all of the strains were maintained frozen at $-80^{\circ} \mathrm{C}$ in de Man, Rogosa, and Sharpe (MRS) broth (Laboratorios Britania, Buenos Aires, Argentina) supplemented with $15 \%$ (vol/vol) glycerol as a cryoprotective agent. Before use, the strains were grown overnight twice in MRS broth. 


\section{Cheesemaking and Preparation of Extracts}

Manufacturing the Reggianito cheeses and preparing the soluble extracts was performed according to Milesi et al. (2011). Briefly, Reggianito cheeses were manufactured using single cultures of Lactobacillus helveticus Lh138 or Lh209 incubated in sterile whey to obtain starter cultures, as previously described by Candioti et al. (2002). Two 4-kg cheeses were obtained from each batch, which were ripened at $12^{\circ} \mathrm{C}$ and $80 \%$ relative humidity.

Soluble extracts were prepared from these 2 cheeses at different stages of ripening: at $\mathrm{d} 3$ after manufacture (young cheese, y), after ripening for $90 \mathrm{~d}$ (mediumripened cheese, $\mathbf{m}$ ), and after manufacture for $180 \mathrm{~d}$ (fully ripened cheese, f). Before preparing the extracts, the $\mathrm{pH}$ (Bradley et al., 1993), DM content (oven drying at $102 \pm 1{ }^{\circ} \mathrm{C}$; IDF, 1982), protein content (Kjeldahl method; IDF, 1993), and lactose concentration (HPLC according to Bouzas et al., 1991) in all of the cheeses were determined.

To prepare the extracts, cheese and water (1:1) were mixed using a blender, and then the mix was centrifuged $(20 \mathrm{~min}$ at $3,000 \times g)$. The aqueous phase was recovered, filtered through paper (Whatman no. 42) and then through a glass wool disposable prefilter (Millipore Industria e Comercio Ltda, Sao Paulo, Brazil). The salt content and $\mathrm{pH}$ were adjusted to the target values of $5.0 \%$ and 5.20 , respectively, to approximate the composition of the aqueous phase of Reggianito cheese. The extracts were sterilized by filtration through membranes with $0.45-\mu \mathrm{m}$ diameter pores (Millipore Industria e Comercio Ltda).

\section{Inoculation and Incubation of Extracts}

The sterile extracts $(50 \mathrm{~mL})$ were placed in sterile bottles. For each type of Reggianito cheese (Lh209 or Lh138 starters), 3 soluble extracts were prepared: a control that was not inoculated $(\mathbf{C O N})$, an experimental that was inoculated with Lb. plantarum I91 (EXP), and a blank that remained uninoculated and in which the enzymes were inactivated by heating it for $30 \mathrm{~min}$ at $70^{\circ} \mathrm{C}$ in a water bath $(\mathbf{B L})$. Lactobacillus plantarum I91 was inoculated to achieve an initial level of $5 \times 10^{4}$ $\mathrm{cfu} / \mathrm{mL}$. All of the extracts were prepared in duplicate, aliquoted into a series of sterile tubes, and incubated at $34^{\circ} \mathrm{C}$ for $21 \mathrm{~d}$.

\section{Sampling and Analysis}

One tube of each extract was removed from the incubator at $0,3,7,14$, and $21 \mathrm{~d}$. The $\mathrm{pH}$ value and the number of microbes were determined at each sampling time. The sterility of the CON and BL extracts was assessed by plating samples on aerobic plate count agar plates and incubating them at $37^{\circ} \mathrm{C}$ for $48 \mathrm{~h}$ (Ugarte et al., 2006). The $L b$. plantarum 191 population in the EXP extracts was enumerated by counting the colonies on MRS agar plates (Laboratorios Britania) after incubating the plates at $34^{\circ} \mathrm{C}$ for $48 \mathrm{~h}$ under microaerophilic conditions (Milesi et al., 2010).

To determine the course of proteolysis, the peptide and free amino acid profiles were determined throughout the incubation of the extracts. The peptide profiles were obtained using reversed-phase HPLC according to Hynes et al. (2003) at $0,3,7,14$, and $21 \mathrm{~d}$ of incubation. The individual free amino acids were quantified using a precolumn derivatization method (AccQ-Tag; Waters Corp., Milford, MA), as described by Bergamini (2007) in samples from 0, 3, 7 and $14 \mathrm{~d}$ of incubation because preliminary assays had shown little change in the free amino acids (FAA) content after $14 \mathrm{~d}$. The total FAA content (TFAA) was calculated as the sum of the individual quantities of FAA.

\section{Statistics}

The mean values of the individual and total contents of FAA and the $\mathrm{pH}$ of all extracts, as well as average levels of lactobacilli in EXP extracts, were compared using a one-way ANOVA. The mean values were grouped according to the results of the least significant difference test. Statistical analysis was performed using SPSS 10.0 software (SPSS Inc., Chicago, IL).

\section{RESULTS}

\section{Cheese Composition and Evolution of $\mathrm{pH}$}

The composition and $\mathrm{pH}$ of the cheeses made with Lh209 or Lh138 were similar at each ripening point; the moisture content, protein content, and lactose concentration comprised between 36.1 to $37.4 \%, 28.7$ to $29.4 \%$, and 0.03 to $0.05 \%$ in the young cheeses, respectively. In the 90- and 180-d-old cheeses, the moisture content was somewhat lower (35.0 to $36.8 \%$ ), which is typical for cheeses ripened without wrapping, and the protein content was concomitantly increased. Lactose was not detected in the cheeses ripened for 90 and $180 \mathrm{~d}$. The $\mathrm{pH}$ of the cheeses increased slightly during ripening, from 5.15 to 5.30 .

The initial $\mathrm{pH}$ was the same in all of the extracts because it was adjusted before inoculation with the lactobacilli. The target value was 5.20 and the actual $\mathrm{pH}$ of all of the extracts was $5.25 \pm 0.01$. During incubation, the $\mathrm{pH}$ remained constant in all of the $\mathrm{BL}$ and $\mathrm{CON}$ extracts prepared from the $\mathrm{y}, \mathrm{m}$, and $\mathrm{f}$ Reggianito 


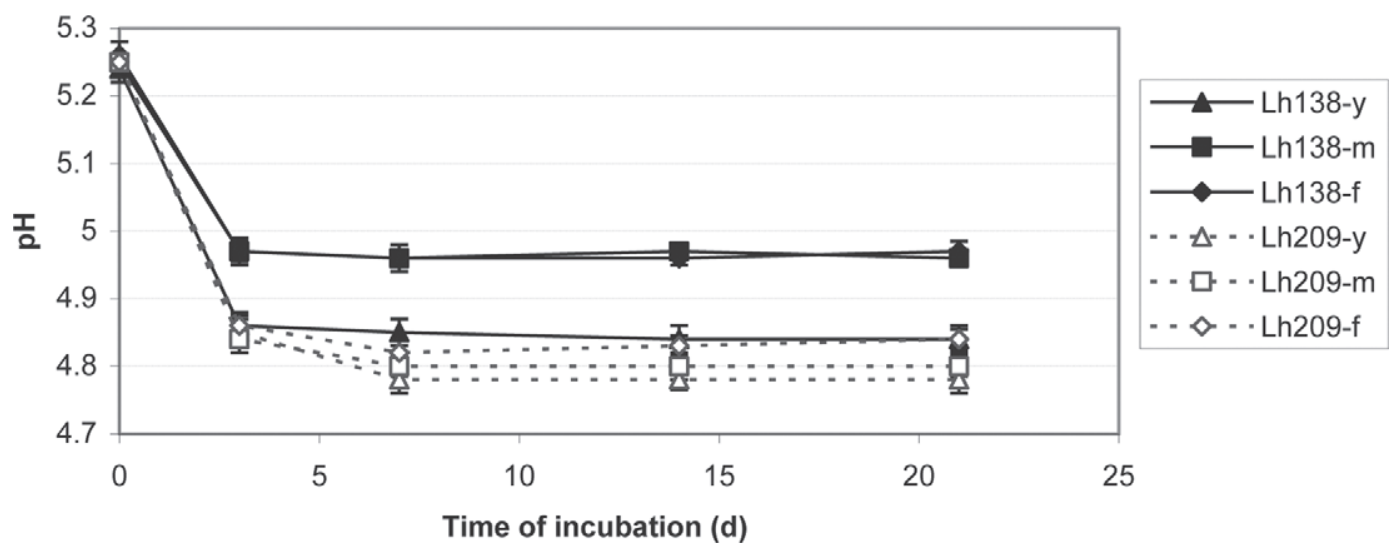

Figure 1. Evolution of pH during incubation in experimental extracts of young (y), medium-ripened (m), and fully ripened (f) Reggianito cheeses made with Lactobacillus helveticus 138 (Lh138; solid lines) or Lb. helveticus 209 (Lh209; dashed lines) and inoculated with Lactobacillus plantarum I91.

cheeses made with Lh209 or Lh138 starters (data not shown). In contrast, a decrease in $\mathrm{pH}$ was observed in all of the EXP extracts from the start of incubation to $7 \mathrm{~d}$; afterward, the $\mathrm{pH}$ remained constant until the end of incubation (Figure 1).

In all of the extracts of the Lh209 cheeses, the evolution of $\mathrm{pH}$ was very similar: a pronounced decrease of approximately 0.4 units occurred between 0 and 3 $\mathrm{d}$, followed by a further decrease between 3 and $7 \mathrm{~d}$. The final $\mathrm{pH}$ values of the Lh209 cheese extracts were between 4.78 and 4.82 ; the highest values were found in the $\mathrm{f}$ extracts and the lowest, in y extracts.

In the extracts from the Lh138 cheeses, the pattern was different: an initial decrease of 0.3 units occurred between 0 and $3 \mathrm{~d}$ of incubation, and then the $\mathrm{pH}$ remained constant until d 21. The smallest decrease in $\mathrm{pH}$ was found in the $\mathrm{m}$ and $\mathrm{f}$ extracts of the Lh138 cheese; their $\mathrm{pH}$ between 3 and $21 \mathrm{~d}$ of incubation was significantly $(P \leq 0.05)$ higher (approximately 0.1 units) than the $\mathrm{pH}$ of all of the other EXP extracts (the $y$ extract of the Lh138 cheese and the $y, m$, and $\mathrm{f}$ extracts of the Lh209 cheese).

These results may be related to the residual concentration of carbohydrates (lactose and galactose) of the cheeses used for the extract preparations, which varied with the time of ripening. The greatest acidification was found in the y extracts, prepared with cheeses that had $0.04 \pm 0.01 \%$ lactose, whereas the levels of this carbohydrate were undetectable in the cheeses that had ripened for 90 and $180 \mathrm{~d}$, which were used for preparation of the $\mathrm{m}$ and $\mathrm{f}$ extracts, respectively. The differences between extracts from cheeses made with different starter cultures were not due to their lactose content because it was similar in both the Lh209 and Lh138 cheeses of the same age. However, in the cheeses manufactured with $L b$. helveticus as a starter, the galactose moiety of lactose is hydrolyzed due to this species' ability to ferment this sugar (Hickey et al., 1986; Di Cagno and Gobbetti, 2011). Consequently, it is likely that the profile of galactose during Reggianito cheese ripening is similar to that of lactose (i.e., a higher concentration of galactose may be present in the young cheeses, but its concentration would decrease with increasing ripening time).

\section{Microbiological Counts}

No microbial growth occurred in the BL or CON extracts during incubation. This result confirms the efficacy of filtration through $0.45-\mu \mathrm{m}$ membranes as a sterilization method and is in agreement with the constant $\mathrm{pH}$ observed during incubation.

The counts of $L b$. plantarum I91 in the EXP extracts are shown in Figure 2. The initial level was $4.5 \log \mathrm{cfu} /$ $\mathrm{mL}$ in all of the extracts. Then, the number of lactobacilli increased, reaching levels of 8.2 and 8.6 log cycles in the extracts of the Lh209 and Lh138 cheeses, respectively. No differences were found in the maximal level of lactobacilli in the extracts obtained from cheeses of different ages $(P \geq 0.05)$, but the age of the cheese affected the decrease in viability that followed, between 3 and $21 \mathrm{~d}$ of incubation. In this way, the $L b$. plantarum I91 counts decreased the most in the y extracts, which were those that underwent the greatest decrease in $\mathrm{pH}$. The counts of $L b$. plantarum I91 decreased to ca. 5 log at $14 \mathrm{~d}$ of incubation in both Lh209 and Lh138 cheese y extracts; this level remained constant in the extracts of the Lh209 cheeses, whereas it showed a further decrease (to ca. $3 \mathrm{log}$ ) in the y extract of the Lh138 cheese. The evolution of $L b$. plantarum I91 population was rather similar in both of the $\mathrm{m}$ and $\mathrm{f}$ extracts, but the final level at $21 \mathrm{~d}$ of incubation was significantly higher in the extracts of the Lh138-ripened cheeses than in those of the Lh209-ripened cheeses (6 log vs. 5 log, respectively). The final lactobacilli level was ca. $5 \log$ in all 


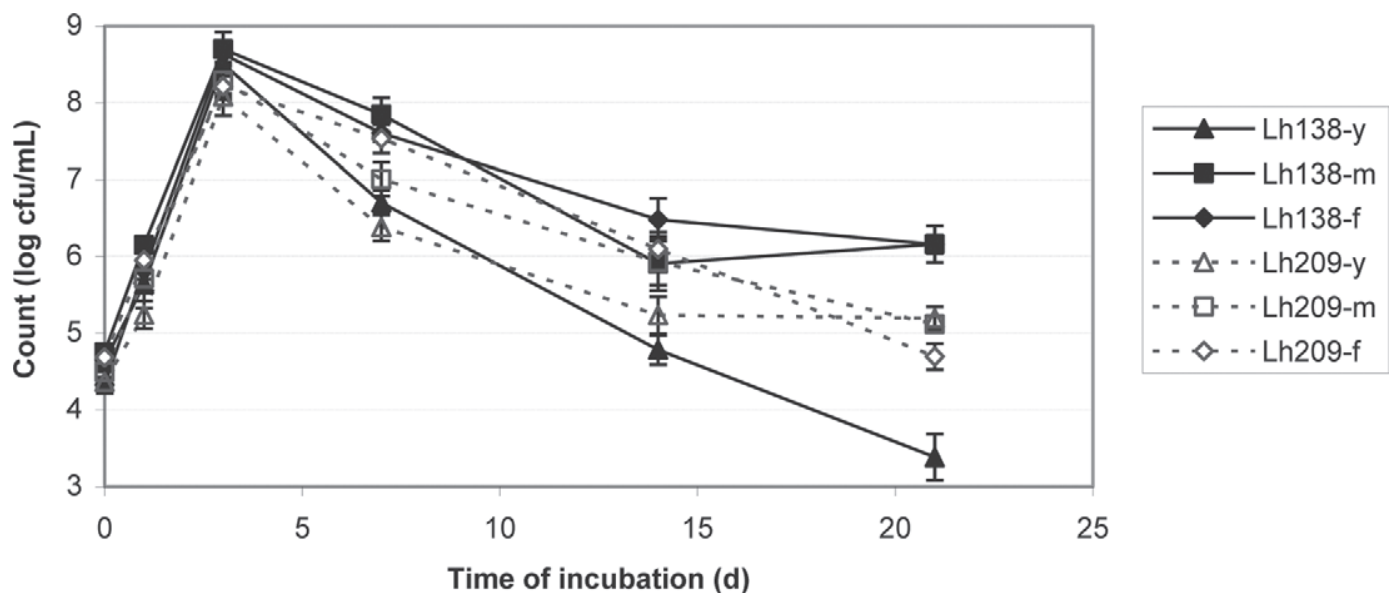

Figure 2. Evolution of Lactobacillus plantarum I91 population size in experimental extracts obtained from young (y), medium-ripened (m), and fully ripened (f) Reggianito cheeses made with Lactobacillus helveticus 138 (Lh138; solid lines) or Lb. helveticus 209 (Lh209; dashed lines).

of the extracts of the Lh209 cheese, regardless the age of cheese. In contrast, the $L b$. plantarum I91 counts in the extracts of the Lh138 cheeses at $21 \mathrm{~d}$ of incubation were significantly different: the $m$ and $f$ extracts had ca. $3 \log$ higher lactobacilli counts than did the y extract.

\section{FAA}

The TFAA value did not change in BL extracts during incubation, whereas the TFAA increased in the EXP and CON extracts during incubation. The extent of the TFAA increase varied according to the aging time and the primary starter strain of the cheeses used for extract preparation.

The initial levels of the TFAA were higher in the extracts of cheeses that had ripened longer because of the evolution in proteolysis that occurs during ripening (Figures $3 \mathrm{~A}$ and $\mathrm{B}$ ). At the start of incubation, the $\mathrm{y}$ extracts of the Lh209 and Lh138 cheeses had similar levels of TFAA (Figure 3). When the cheese age increased, the initial proteolysis in the extracts differed according to the $L b$. helveticus strain used as a starter for cheesemaking: the TFAA contents of the $\mathrm{m}$ and $\mathrm{f}$ extracts of the Lh138 cheese were significantly higher than those of the Lh209 cheese (Figures 3A and B; $P \leq 0.05$ ). As for the influence of $L b$. plantarum I91, in general, no significant differences were observed between the TFAA increases in the CON and EXP extracts during incubation, although slight variation was observed. For Lh138 extracts, the TFAA content of the EXP and CON extracts were very similar throughout the incubation. For the Lh209 cheese extracts, the EXP extracts always exhibited a lower TFAA level than those of the CON extracts, but significant differences were found only in the $\mathrm{y}$ extracts at $14 \mathrm{~d}$ of incubation $(P \leq 0.05)$.
The differences in the concentration of each FAA in the EXP extracts and their respective $\mathrm{CON}$ at 7 and $14 \mathrm{~d}$ were quantified as percentages (Figure 4). In the $y$ extracts (Figure 4A), the levels of all of the FAA generally decreased in the EXP extracts in relation to CON extracts, with a few exceptions. In addition, the differences were slightly higher for the Lh209 extracts. An opposite trend was found for the Lh138 and Lh209 m extracts: most of the FAA increased in Lh138 cheese extracts containing $L b$. plantarum $\mathrm{I} 91$ in relation to the respective $\mathrm{CON}$, whereas most of the FAA decreased in the Lh209 extracts containing $L b$. plantarum I91 (Figure 4B). Finally, the evolution of FAA profile in the $f$ extracts was very similar to that of the $m$ extracts (Figure 4C).

\section{Peptide Profiles}

The soluble peptide profiles of the BL extracts did not change during incubation, with the exception of an increase of the peak areas in the chromatogram zone between 65 to $75 \mathrm{~min}$ (data not shown). In contrast, the peptide profiles of the $\mathrm{y}, \mathrm{m}$, and $\mathrm{f}$ CON and EXP extracts showed evident changes during incubation (Figures 5 and 6). In general, the profiles evolved during incubation toward an increase in the number/area of peaks in the initial zone of the chromatogram (between 0 to $30 \mathrm{~min}$, approximately), and a concomitant decrease in the number/area of peaks in the middle and the end part of the profile (between 30 to $95 \mathrm{~min}$, approximately). The peptide profiles in the y extracts of the Lh138 and Lh209 cheeses were similar; they evolved toward completely different patterns as ripening and incubation progressed (i.e., in the $\mathrm{m}$ and $\mathrm{f}$ extracts; Figures 5 and 6). 

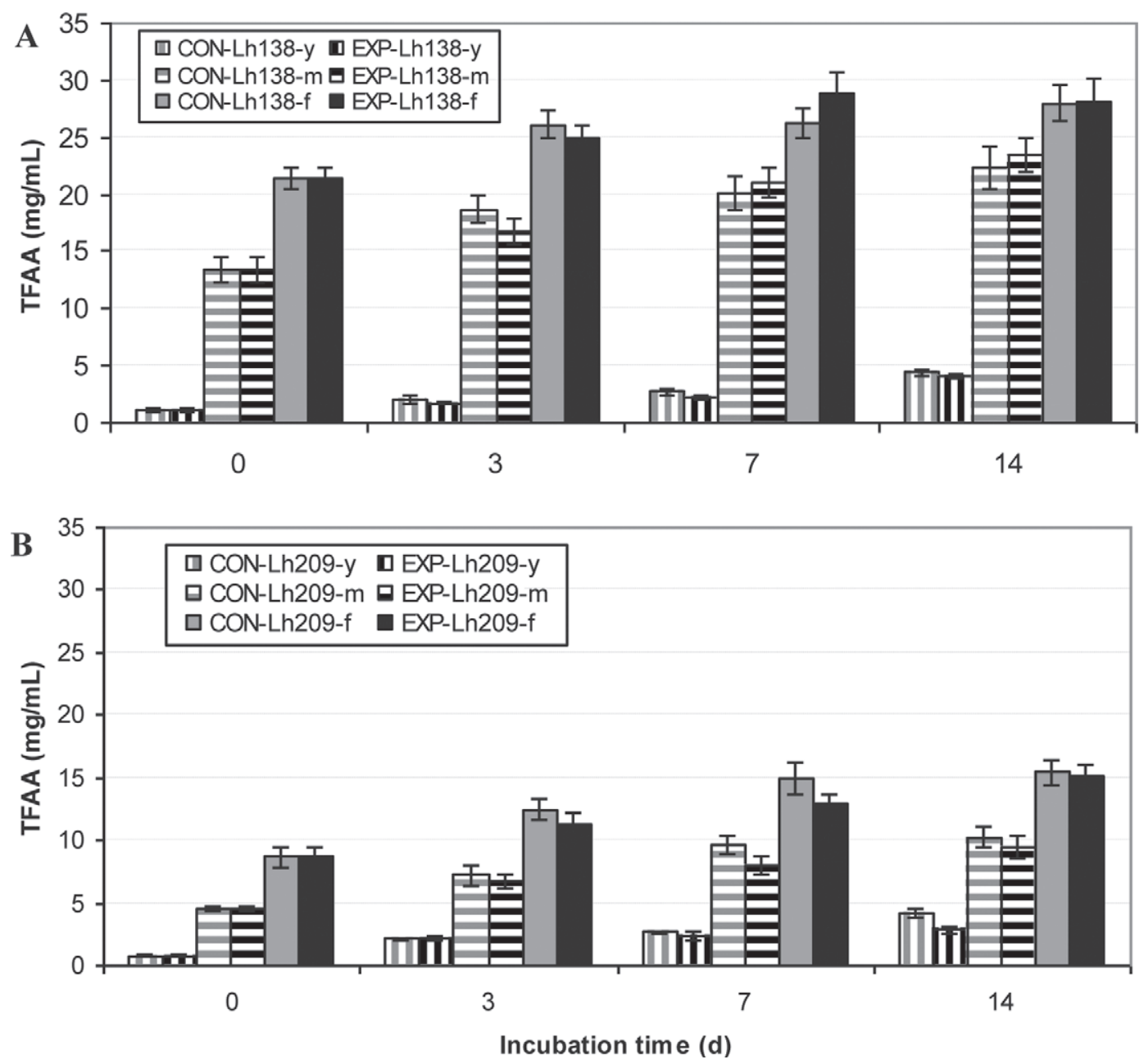

Figure 3. Total free amino acids (TFAA) in control (CON; extracts that were not inoculated) and experimental (EXP; extracts inoculated with Lactobacillus plantarum I91) cheese extracts during incubation. (A) Extracts obtained from young (y), medium-ripened (m), and fully ripened (f) Reggianito cheeses manufactured using Lactobacillus helveticus 138 as the primary starter; (B) extracts obtained from y, m, and f Reggianito cheeses manufactured using $L b$. helveticus 209 as the primary starter.

The effect of Lb. plantarum 191 on the peptide profiles was marginal: very few differences were found between the peptide profiles of the CON and EXP extracts, for both the Lh138 (Figure 5) and the Lh209 (Figure 6) cheeses. When differences between the peptide profiles of the extracts incubated with and without $L b$. plantarum I91 were found, they occurred in the $\mathrm{y}$ extracts rather than in the $\mathrm{m}$ and $\mathrm{f}$ extracts. The main differences among the peptide profiles of the different extracts were found between 5 and $10 \mathrm{~min}$, at approximately $24 \mathrm{~min}$, at approximately $40 \mathrm{~min}$, and between 65 and $75 \mathrm{~min}$.

\section{DISCUSSION}

Although the NSLAB can metabolize a great variety of substrates in cheeses, residual lactose has been reported to be necessary for the growth of the NSLAB at the beginning of ripening (Williams et al., 2000; Beresford, 2003). However, the growth and maintenance of a high level of NSLAB after several weeks of ripening, when the lactose is exhausted, demonstrates that this compound is not the only energy source (Fox et al., 1998; Banks and Williams, 2004).

In our study, the growth of $L b$. plantarum I91 was quite similar in the extracts obtained from cheeses of different ages, which contained different levels of lactose, from $0.04 \%$ to undetectable levels $(\leq 0.01 \%)$. Similarly, Díaz-Muñiz and Steele (2006) observed that Lb. casei ATCC334 reached almost $10^{9} \mathrm{cfu} / \mathrm{mL}$ in a Cheddar cheese extract after $200 \mathrm{~h}$ of incubation (ca. $8 \mathrm{~d}$ ) in the presence of both excess (52 $\mathrm{m} M$ total hexose) and limiting carbohydrate (2.6 $\mathrm{m} M$ total hexose). Similarly, Shakeel-Ur-Rehman et al. (2004) suggested that no lactose is needed for the growth of NSLAB in Cheddar cheese because they obtained similar lactoba- 

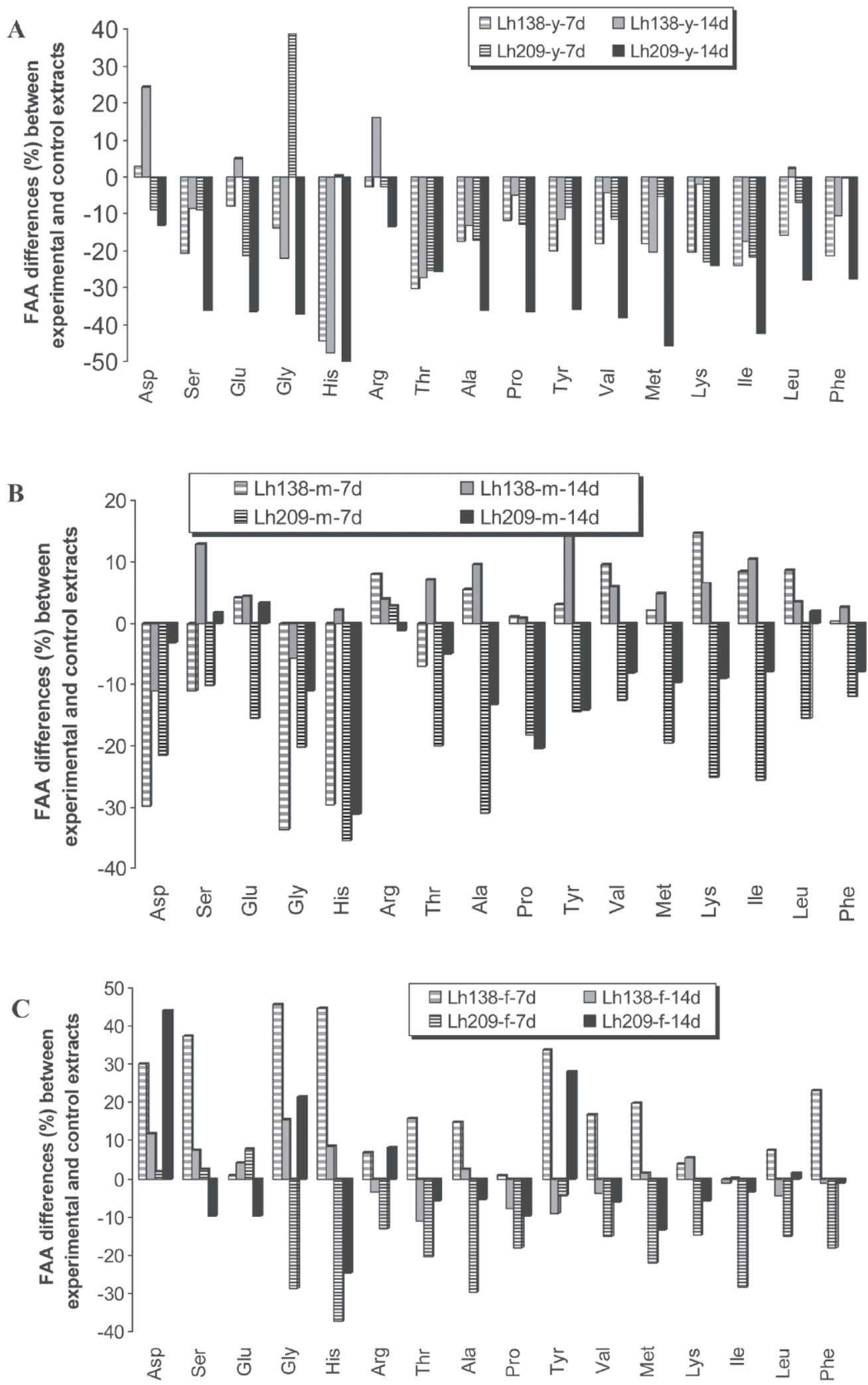

Figure 4. Percentage differences between the levels of free amino acids (FAA) in the experimental extracts inoculated with Lactobacillus plantarum $\mathrm{I} 91$ in relation to their respective control extracts at 7 and $14 \mathrm{~d}$ of incubation. (A) Extracts of young (y) Reggianito cheeses, (B) extracts of medium-ripened (m) Reggianito cheeses $(90 \mathrm{~d})$, (C) extracts of fully ripened (f) Reggianito cheeses (180 d). Lh138 = Lactobacillus helveticus 138; Lh209 = Lb. helveticus 209. 


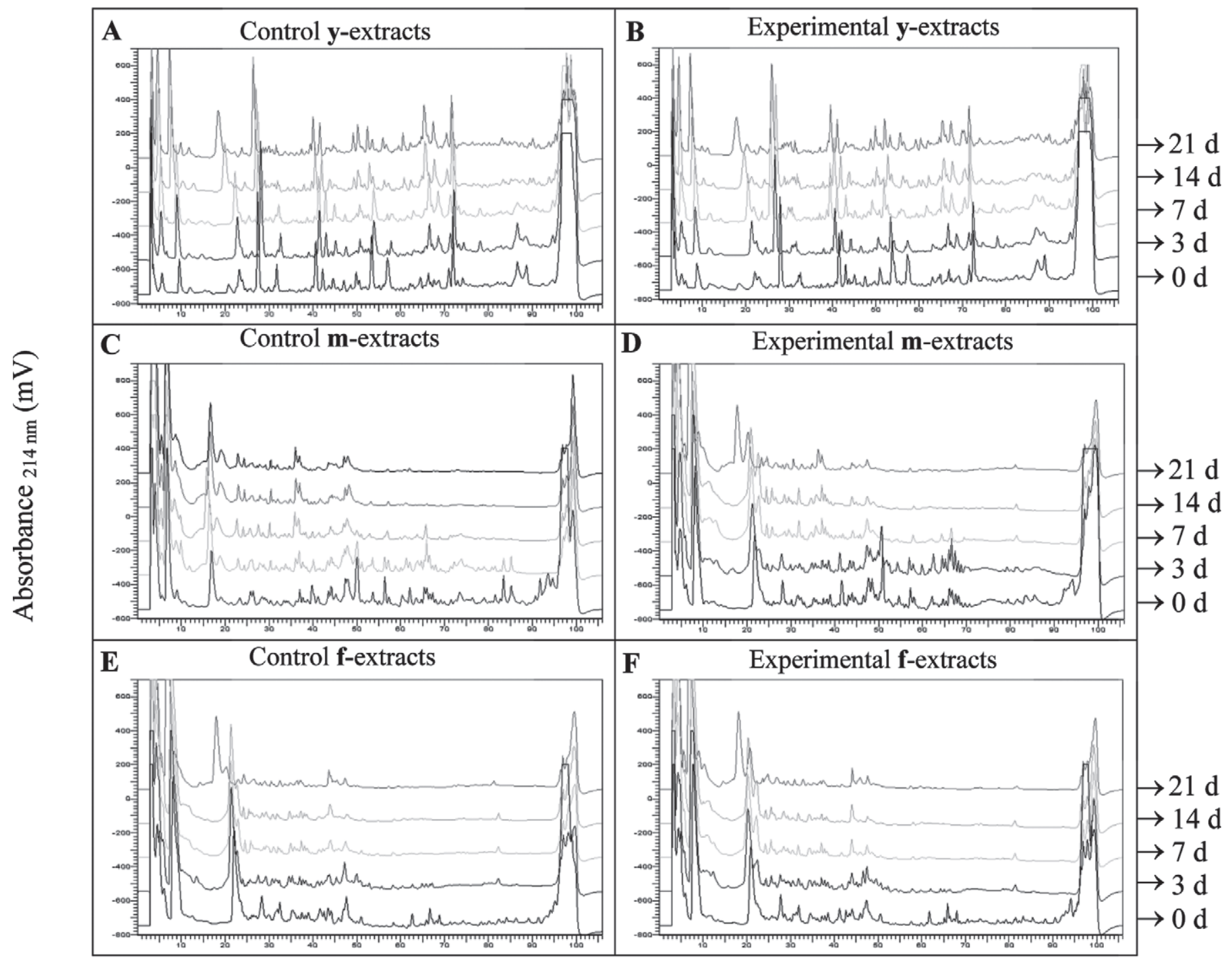

Retention time (min)

Figure 5. Peptide profiles determined by reversed-phase HPLC of control (A, C, and E) and experimental (B, D, and F) extracts during incubation $(0,3,7,14$, and $21 \mathrm{~d}$ ). Extracts were obtained from young (y; A and B), medium-ripened (m; C and D), and fully ripened (f; E and F) Reggianito cheeses manufactured using Lactobacillus helveticus 138 (Lh138) as the primary starter. Control: extracts that were not inoculated; experimental: extracts that were inoculated with Lactobacillus plantarum I91.

cilli counts in cheeses with different levels of lactose, although the minimal concentration of lactose obtained by these authors in young Cheddar cheeses may have been sufficient to initiate NSLAB growth. In contrast to these results, Budinich et al. (2011) observed that the ability of a Cheddar cheese extract to support the growth of Lb. paracasei ATCC334 decreased as the ripening time of the Cheddar cheese used to prepare the medium increased: the differences between those results and ours may be due to the diverse nutrients available in the cheese extracts, the time of incubation, and differences in species and strains. Additionally, Hussain et al. (2009) showed that the population of $L b$. casei GCRL163 increased during incubation in a tryptonebased defined medium containing 0.2 or $1 \%$ of lactose, but they did not detect any growth in a medium lacking lactose. The survival of $L b$. casei GCRL163, however, was better in the lactose-deficient medium.

However, several strains of different lactic acid bacteria that can use amino acids and small peptides as energy sources under sugar starvation conditions have been reported (Ganesan et al., 2007; Skeie et al., 2008; Brandsma et al., 2012; Sinz and Schwab, 2012). According to our results, although the maximal level of 


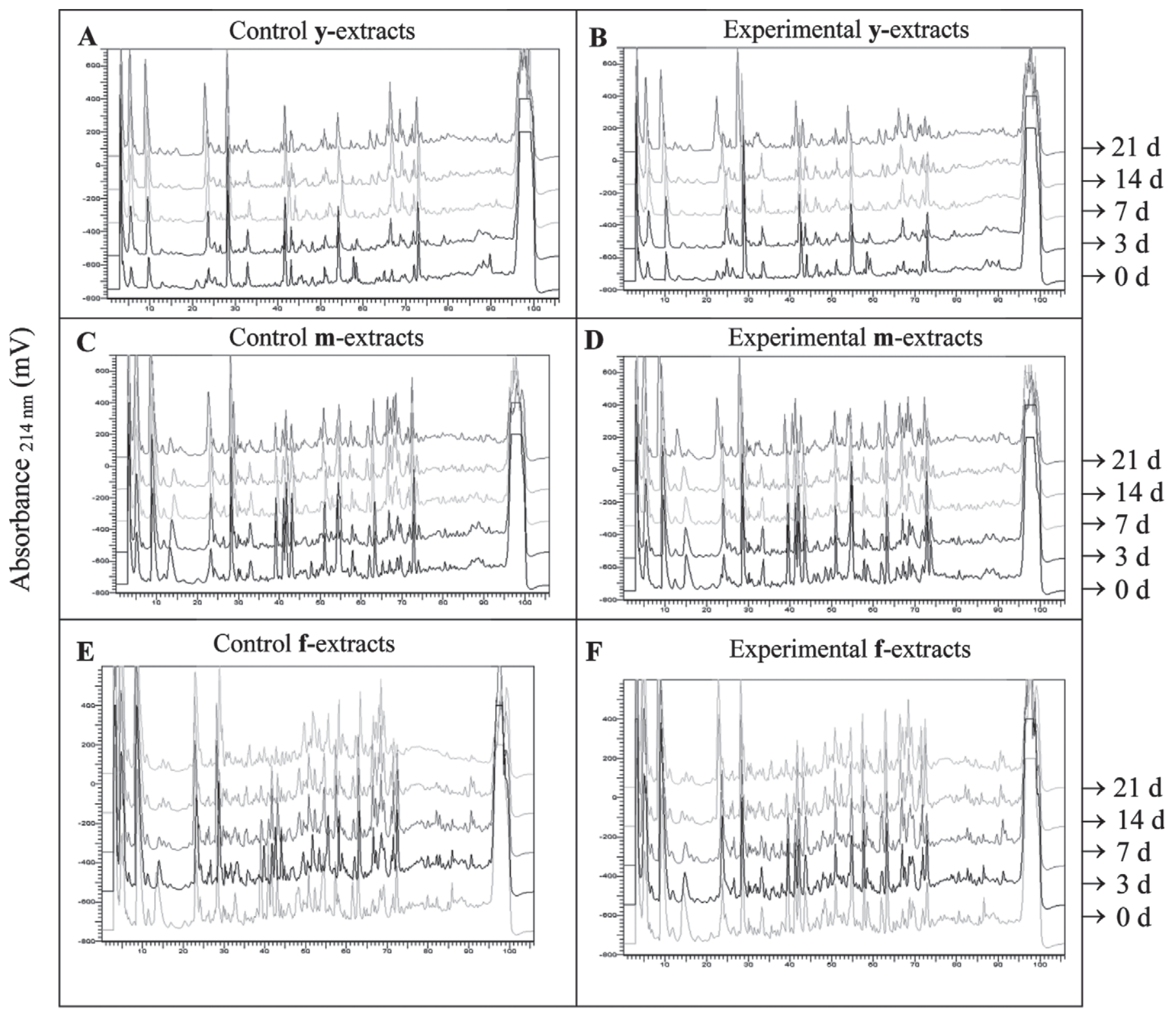

\section{Retention time (min)}

Figure 6. Peptide profiles obtained by reversed-phase HPLC of control (A, C, and E) and experimental (B, D, and F) extracts during incubation $(0,3,7,14$, and $21 \mathrm{~d})$. Extracts were obtained from young (y; A and B), medium-ripened (m; C and D), and fully ripened (f; E and F) Reggianito cheeses manufactured using Lactobacillus helveticus 209 (Lh209) as the primary starter. Control: extracts that were not inoculated; experimental: extracts that were inoculated with Lactobacillus plantarum I91.

lactobacilli was equal in all extracts, viability of $L b$. plantarum I91 was best maintained in the Lh138 cheese $\mathrm{m}$ and $\mathrm{f}$ extracts, which contained at least twice as much TFAA as the Lh209 $\mathrm{m}$ and $\mathrm{f}$ extracts, and no lactose.

In extracts of the young cheeses of both the Lh209 and Lh138 types, the viability of $L b$. plantarum I91 correlated with the environmentally unfavorable conditions, mainly the $\mathrm{pH}$ decrease and, probably, the in- crease in inhibitor compounds, such as lactate, as well as the depletion of energy sources such as lactose and others (Kieronczyk et al., 2001; Hussain et al., 2009). Similarly, Hussain et al. (2009) observed a detrimental effect of lactate on the viability of $L b$. casei GCRL163 during prolonged exposure (30 d in a chemically defined medium at $30^{\circ} \mathrm{C}$ ). The differences in the $\mathrm{pH}$ and cell viability values for the Lh138- and Lh209-ripened cheese extracts ( $\mathrm{m}$ and $\mathrm{f}$ extracts), in which the lactose 
concentration was below the detection limit, may be due to different residual galactose contents in the 2 types of cheeses; however, we did not determine the galactose content of the extracts.

The amino acid content at a given time of incubation is the result of the balance between their release in the peptidolysis and their catabolism, as well due to other chemical reactions involving FAA. In the CON extracts, catabolism of amino acids was not possible because there were no viable cells, only proteolytic and peptidolytic enzymes: residual coagulant, plasmin, and, more importantly-because it differed from Lh209 to Lh138 cheeses - enzymes released from the cells of the starter strain of $L b$. helveticus. In both CON extracts, the TFAA release showed a positive slope during incubation, but the TFAA release was much greater in Lh138 than in Lh209 cheese extracts, as shown in Figures $3 \mathrm{~A}$ and $\mathrm{B}$, respectively. The peptide profiles of the CON extracts were correlated with the FAA release in Lh138 cheese extracts; a decrease in the number and areas of peaks during ripening and with increased incubation time was observed, concomitant with increased peptide hydrolysis and FAA release. In the Lh209 extracts, an increase in the number and areas of the peaks was observed with the increasing ripening of the cheese used for the extracts or the incubation time, or both. These observations suggest that the Lh209 cheeses and extracts were in a prior state of proteolysis compared with the Lh138 cheeses and extracts of the same ripening status or incubation period, which is consistent with the results reported by Milesi et al. (2011).

The very different initial proteolysis profiles of the extracts did not significantly influence the proteolytic and peptidolytic activity of $L b$. plantarum I91 because only marginal changes were detected in the EXP extracts compared with the CON extracts. Although $L b$. plantarum I91 grew, acidified the medium and remained viable during incubation in all of the extracts, few changes in peptide production were attributable to its activity, and those were mostly in young (y) extracts.

In this hard-cheese model, the small contribution of Lb. plantarum I91 to peptidolysis indicates that the influence of the NSLAB and their enzymes may be secondary compared with that of all the other proteolytic agents present in this type of cheese. Gatti et al. (1999) reported that the enzymatic pattern of mature Italian cheese is determined by the type of starter used in cheesemaking, which is consistent with the differences between the extracts observed in our study. It is possible that the proteolytic activity due to the peptidases released by the starter cultures of $L b$. helveticus masked the peptidolytic activity of $L b$. plantarum I91. In this way, a high concentration of different peptidases was found in cheeses manufactured with thermophilic lactobacilli, such as Grana Padano and Parmigiano-Reggiano, or with a starter composed of Strep. thermophilus and thermophilic lactobacilli, such as Sbrinz, Swiss Gruyere, Pecorino Romano, and Provolone. The levels of peptidase activities in these cheeses were the highest in comparison with those of other cheeses, which contained only mesophilic starters and had a shorter ripening period (Gatti et al., 1999).

We also proposed that plasmin activity most likely had an influence on production and hydrolysis of hydrophobic peptides in the extracts. Heat-treated BL extracts showed increased areas for the peaks of the zone of 65 to $75 \mathrm{~min}$, which are likely caused by heatresistant indigenous protease of milk, plasmin (Kelly and O'Donnell, 1998). Hydrophobic peaks were much lower in EXP y extracts compared with CON y extracts, likely because the low $\mathrm{pH}$ inhibited plasmin activity (Bastian and Brown, 1996).

Several mesophilic lactobacilli strains have shown an influence on proteolysis in hard cheeses, but in these cases, the primary starter was composed of lactococci strains and the cheese model was Cheddar, which is cooked to a lower maximum scald than Reggianito cheese (Lane and Fox, 1996; Lynch et al., 1996, 1997). However, Lb. plantarum I91 had a significant influence on the production of soluble peptides and the increase in FAA in Cremoso, Cheddar, and Pategrás cheeses (Milesi et al., 2008, 2009). In those research studies, the starter cultures consisted of Strep. thermophilus strains for the Cremoso and Pategrás cheeses and Lactococcus lactis strains for the Cheddar cheese. The present model offered a much more complex background for $L b$. plantarum I91 so that its influence on peptidolysis was not significant.

Finally, regarding the individual and total FAA contents, some changes due to the inoculation of $L b$. plantarum I91 in the extracts were detected. The effect of medium composition on the metabolic activity of lactic acid bacteria has been demonstrated by several authors. In this sense, the high availability of FAA and small peptides led to a lower production of proteolytic enzymes by Lc. lactis and some strains of lactobacilli, but this regulation has been shown to be strain dependent (Meijer et al., 1996; Hebert et al., 2000; Savijoki et al., 2006). In our work, the neat balance of FAA in the extracts at each sampling point during incubation indicates that catabolism of FAA of $L b$. plantarum I91 prevailed in a medium containing low levels of FAA, such as all of the Lh209 extracts and the Lh138 y extract, whereas the release of amino acids by $L b$. plantarum I91 largely overcame the effects of catabolism in a medium with high levels of amino acids, such as the Lh138 extracts. Liu et al. (2003) have demonstrated a variable ability between different strains of $L b$. plan- 
tarum to metabolize or produce specific amino acids. With regard to the capability of the Lb. plantarum 91 for metabolize amino acids, we have found aminotransferase activity toward Asp and branched and aromatic amino acids (results not published).

\section{CONCLUSIONS}

In the present study, we found that Lb. plantarum I91, an NSLAB strain, grew to similar levels in hardcheese extracts regardless of differences in their lactose concentration, FAA content, and available peptides. The differences in the composition of the extracts were caused by the $L b$. helveticus starter strain of the 2 cheeses and their ripening periods. Lactobacillus plantarum I91 was able to use energy sources other than lactose to reach an equivalent maximal population size in all of the extracts at $3 \mathrm{~d}$ of incubation. Further survival of $L b$. plantarum I91 up to $21 \mathrm{~d}$ of incubation was significantly higher in extracts with the highest levels of FAA and peptides and the lowest acidification rates. Lactobacillus plantarum I91 did not affect the quantities of peptidolytic product or the differential peptide production according to the initial proteolysis profile of the extract, indicating that the effect of the NSLAB on proteolysis in hard-cooked cheeses may be secondary. The influence of the strain of $L b$. helveticus used as a starter culture on $L b$. plantarum I91 metabolism was mainly exerted on FAA release/catabolism.

\section{REFERENCES}

Banks, J. M., and A. G. Williams. 2004. The role of nonstarter lactic acid bacteria in Cheddar cheese ripening. Int. J. Dairy Technol. $57: 145-152$.

Bastian, E. D., and R. J. Brown. 1996. Plasmin in milk and dairy products: An update. Int. Dairy J. 6:435-457.

Beresford, T. 2007. What are non-starter lactic acid bacteria and how they affect cheese quality? Pages 124-130 in Cheese Problems Solved. P. L. H. McSweeney, ed. Woodhead Publishing Ltd., Abington, UK.

Beresford, T. P. 2003. Non-starter lactic acid bacteria (NSLAB) and cheese quality. Pages 448-469 in Dairy Processing: Improving Quality. G. Smit, ed. CRC Press, Cambridge, UK.

Bergamini, C. V. 2007. Influencia de la adición de bacterias probióticas sobre el perfil de proteólisis de quesos semiduros. Doctoral Thesis. Facultad de Bioquímica y Ciencias Biológicas, Universidad Nacional del Litoral, Santa Fe, Argentina.

Bouzas, J., C. A. Kantt, F. Bodyfelt, and J. A. Torres. 1991. Simultaneous determination of sugars and organic acids in Cheddar cheese by high-performance liquid chromatography. J. Food Sci. 56:276-278.

Bradley, R. L., E. Arnold, D. M. Barbano, R. G. Semerad, D. E. Smith, and B. K. Vines. 1993. Chemical and physical methods. Pages 433-531 in Standard Methods for the Examination of Dairy Products. R. Marshall, ed. American Public Health Association, Washington, DC.

Brandsma, J. B., I. van de Kraats, T. Abee, M. H. Zwietering, and W. C. Meijer. 2012. Arginine metabolism in sugar deprived Lactococcus lactis enhances survival and cellular activity, while supporting flavour production. Food Microbiol. 29:27-32.
Budinich, M. F., I. Perez-Díaz, H. Cai, S. A. Rankin, J. R. Broadbent, and J. L. Steele. 2011. Growth of Lactobacillus paracasei ATCC 334 in a cheese model system: A biochemical approach. J. Dairy Sci. 94:5263-5277.

Candioti, M. C., E. Hynes, A. Quiberoni, S. B. Palma, N. Sabbag, and C. A. Zalazar. 2002. Reggianito Argentino cheese: Influence of Lactobacillus helveticus strains isolated from natural whey cultures on cheese-making and ripening processes. Int. Dairy J. 12:923-931.

Chopard, M.-A., M. Schmitt, E. Perreard, and J.-F. Chamba. 2001. Aspect qualitatif de l'activité protéolytique des lactobacilles thermophiles utilisés en fabrication de fromages à pâte pressée cuite. Lait 81:183-194.

Crow, V., B. Curry, and M. Hayes. 2001. The ecology of non-starter lactic acid bacteria (NSLAB) and their use as adjuncts in New Zealand Cheddar. Int. Dairy J. 11:275-283.

Di Cagno, R., M. De Angelis, V. K. Upadhyay, P. L. H. McSweeney, F. Minervini, G. Gallo, and M. Gobbetti. 2003. Effect of proteinases of starter bacteria on the growth and proteolytic activity of Lactobacillus plantarum DPC2741. Int. Dairy J. 13:145-157.

Di Cagno, R., and M. Gobbetti. 2011. Lactobacillus spp.: Lactobacillus helveticus. Pages 105-110 in Encyclopedia of Dairy Sciences. J. Fuquay, P. F. Fox, and P. L. H. McSweeney, ed. Academic Press, London, UK.

Díaz-Muñiz, I., and J. L. Steele. 2006. Conditions required for citrate utilization during growth of Lactobacillus casei ATCC334 in chemically defined medium and Cheddar cheese extract. Antonie van Leeuwenhoek 90:233-243.

Farkye, N. Y., S. A. Madkor, and H. G. Atkins. 1995. Proteolytic abilities of some lactic acid bacteria in a model cheese system. Int Dairy J. 5:715-725.

Fitzsimons, N. A., T. M. Cogan, S. Condon, and T. Beresford. 2001. Spatial and temporal distribution of non-starter lactic acid bacteria in Cheddar cheese. J. Appl. Microbiol. 90:600-608.

Fox, P. F., P. L. H. McSweeney, and C. M. Lynch. 1998. Significance of non-starter lactic acid bacteria in Cheddar cheese. Aust. J. Dairy Technol. 53:83-89.

Ganesan, B., M. R. Stuart, and B. C. Weimer. 2007. Carbohydrate starvation causes metabolically active but nonculturable state in Lactococcus lactis. Appl. Environ. Microbiol. 73:2498-2512.

Gatti, M., M. E. Fornasari, G. Mucchetti, F. Addeo, and E. Neviani. 1999. Presence of peptidase activities in different varieties of cheese. Lett. Appl. Microbiol. 28:368-372.

Hannon, J. A., K. N. Kilcawley, M. G. Wilkinson, C. M. Delahunty, and T. P. Beresford. 2007. Flavour precursor development in Cheddar cheese due to lactococcal starters and the presence and lysis of Lactobacillus helveticus. Int. Dairy J. 17:316-327.

Hannon, J. A., M. G. Wilkinson, C. M. Delahunty, J. M. Wallace, P. A. Morrissey, and T. P. Beresford. 2003. Use of autolytic starter systems to accelerate the ripening of Cheddar cheese. Int. Dairy J. $13: 313-323$.

Hebert, E. M., R. R. Raya, and G. De Giori. 2000. Nutritional requirements and nitrogen-dependent regulation of proteinase activity of Lactobacillus helveticus CRL 1062. Appl. Environ. Microbiol. 66:5316-5321.

Hickey, M. W., A. J. Hillier, and G. R. Jago. 1986. Transport and metabolism of lactose, glucose, and galactose in homofermentative lactobacilli. Appl. Environ. Microbiol. 51:825-831.

Hussain, M. A., D. A. Rouch, and M. L. Britz. 2009. Biochemistry of non-starter lactic acid bacteria isolate Lactobacillus casei GCRL163: Production of metabolites by stationary-phase cultures. Int. Dairy J. 19:12-21.

Hynes, E., J.-C. Ogier, and A. Delacroix-Buchet. 2000. Protocol for the manufacture of miniature washed-curd cheeses under controlled microbiological conditions. Int. Dairy J. 10:733-737.

Hynes, E., J.-C. Ogier, and A. Delacroix-Buchet. 2001. Proteolysis during ripening of miniature washed-curd cheeses manufactured with different strains of starter bacteria and a Lactobacillus plantarum adjunct culture. Int. Dairy J. 11:587-597.

Hynes, E. R., L. Aparo, and M. C. Candioti. 2004. Influence of residual milk-clotting enzyme on $\alpha_{\mathrm{s} 1}$ casein hydrolysis during ripening of Reggianito Argentino cheese. J. Dairy Sci. 87:565-573. 
Hynes, E. R., C. V. Bergamini, V. B. Suárez, and C. A. Zalazar. 2003 Proteolysis on Reggianito Argentino cheeses manufactured with natural whey cultures and selected strains of Lactobacillus helveticus. J. Dairy Sci. 86:3831-3840.

IDF (International Dairy Federation). 1982. Determination of the total solids content (cheese and processed cheese). Standard 4A. IDF, Brussels, Belgium.

IDF (International Dairy Federation). 1993. Milk: Determination of nitrogen content. Standard 20B. IDF, Brussels, Belgium.

Jensen, M. P., F. K. Vogensen, and Y. Ardö. 2009. Variation in caseinolytic properties of six cheese related Lactobacillus helveticus strains. Int. Dairy J. 19:661-668.

Kelly, A. L., and H. J. O'Donnell. 1998. Composition, gel properties and microstructure of Quarg as affected by processing parameters and milk quality. Int. Dairy J. 8:295-301.

Kenny, O., R. J. FitzGerald, G. O'Cuinn, T. Beresford, and K. Jordan. 2006. Autolysis of selected Lactobacillus helveticus adjunct strains during Cheddar cheese ripening. Int. Dairy J. 16:797-804.

Kiernan, R. C., T. P. Beresford, G. O'Cuinn, and K. N. Jordan. 2000. Autolysis of lactobacilli during Cheddar cheese ripening. Ir. J. Agric. Food Res. 39:95-106.

Kieronczyk, A., S. Skeie, K. Olsen, and T. Langsrud. 2001. Metabolism of amino acids by resting cells of non-starter lactobacilli in relation to flavour development in cheese. Int. Dairy J. 11:217-224.

Laht, T.-M., S. Kask, P. Elias, K. Adamberg, and T. Paalme. 2002 Role of arginine in the development of secondary microflora in Swiss-type cheese. Int. Dairy J. 12:831-840.

Lane, C. N., and P. F. Fox. 1996. Contribution of starter and adjunct lactobacilli to proteolysis in Cheddar cheese during ripening. Int. Dairy J. 6:715-728.

Lane, C. N., P. F. Fox, E. M. Walsh, B. Folkertsma, and P. L. H McSweeney. 1997. Effect of compositional and environmental factors on the growth of indigenous non-starter lactic acid bacteria in Cheddar cheese. Lait 77:561-573.

Litopoulou-Tzanetaki, E. 1990. Changes in numbers and kinds of lactic acid bacteria during ripening of Kefalotyri cheese. J. Food Sci. 55:111-113.

Liu, S.-Q., R. Holland, and V. L. Crow. 2003. The potential of dairy lactic acid bacteria to metabolise amino acids via non-transaminating reactions and endogenous transamination. Int. J. Food Microbiol. 86:257-269.

Lynch, C. M., P. L. H. McSweeney, P. F. Fox, T. M. Cogan, and F. D. Drinan. 1996. Manufacture of Cheddar cheese with and without adjunct lactobacilli under controlled microbiological conditions. Int. Dairy J. 6:851-867.

Lynch, C. M., P. L. H. McSweeney, P. F. Fox, T. M. Cogan, and F. D. Drinan. 1997. Contribution of starter lactococci and non-starter lactobacilli to proteolysis in Cheddar cheese with a controlled microflora. Lait 77:441-459.

Mangia, N. P., M. A. Murgia, G. Garau, M. G. Sanna, and P. Deiana. 2008. Influence of selected lab cultures on the evolution of free amino acids, free fatty acids and Fiore Sardo cheese microflora during the ripening. Food Microbiol. 25:366-377.

Meijer, W., J. D. Marugg, and J. Hugenholtz. 1996. Regulation of proteolytic enzyme activity in Lactococcus lactis. Appl. Environ. Microbiol. 62:156-161.

Milesi, M., C. Bergamini, and E. Hynes. 2011. Production of peptides and free amino acids in a sterile extract describes peptidolysis in hard-cooked cheeses. Food Res. Int. 44:765-773.

Milesi, M. M., G. Vinderola, N. Sabbag, C. A. Meinardi, and E. Hynes. 2009. Influence on cheese proteolysis and sensory characteristics of non-starter lactobacilli strains with probiotic potential. Food Res. Int. 42:1186-1196.

Milesi, M. M., P. L. H. McSweeney, and E. Hynes. 2008. Viability and contribution to proteolysis of an adjunct culture of Lactobacillus plantarum in two model cheese systems: Cheddar cheese-type and soft-cheese type. J. Appl. Microbiol. 105:884-892.
Milesi, M. M., I. V. Wolf, C. V. Bergamini, and E. R. Hynes. 2010. Two strains of nonstarter lactobacilli increased the production of flavor compounds in soft cheeses. J. Dairy Sci. 93:5020-5031.

Moe, K. M., T. Faye, R. K. Abrahamsen, H. M. Østlie, and S. Skeie 2012. Growth and survival of cheese ripening bacteria on milk fat globule membrane isolated from bovine milk and its monosaccharides. Int. Dairy J. 25:29-35.

Oberg, C. J., J. R. Broadbent, M. Strickland, and D. J. McMahon. 2002. Diversity in specificity of the extracellular proteinases in Lactobacillus helveticus and Lactobacillus delbrueckii ssp. bulgaricus. Lett. Appl. Microbiol. 34:455-460.

Quiberoni, A., P. Tailliez, P. Quénée, V. Suárez, and J. Reinheimer. 1998. Genetic (RAPD-PCR) and technological diversities among wild Lactobacillus helveticus strains. J. Appl. Microbiol. 85:591596.

Reinheimer, J., A. Quiberoni, P. Tailliez, A. G. Binetti, and V. Suárez. 1996. The lactic acid microflora of natural whey starters used in Argentina on hard cheese production. Int. Dairy J. 6:869-879.

Reinheimer, J. A., V. B. Suárez, N. B. Bailo, and C. A. Zalazar. 1995. Microbiological and technological characteristics of natural whey cultures for Argentinian hard-cheese production. J. Food Prot. $58: 796-799$

Savijoki, K., H. Ingmer, and P. Varmanen. 2006. Proteolytic systems of lactic acid bacteria. Appl. Microbiol. Biotechnol. 71:394-406.

Shakeel-Ur-Rehman, P. L. H. McSweeney, and P. F. Fox. 1998. Protocol for the manufacture of miniature cheeses. Lait 78:607-620.

Shakeel-Ur-Rehman, D. Waldron, and P. F. Fox. 2004. Effect of modifying lactose concentration in cheese curd on proteolysis and in quality of Cheddar cheese. Int. Dairy J. 14:591-597.

Sinz, Q., and W. Schwab. 2012. Metabolism of amino acids, dipeptides and tetrapeptides by Lactobacillus sakei. Food Microbiol. 29:215-223.

Skeie, S., A. Kieronczyk, S. Eidet, M. Reitan, K. Olsen, and H. Østlie. 2008. Interaction between starter bacteria and adjunct Lactobacillus plantarum INF15D on the degradation of citrate, asparagine and aspartate in a washed-curd cheese. Int. Dairy J. 18:169-177.

Smit, G., A. Braber, W. Van Spronsen, G. van den Berg, and F. A. Exterkate. 1995. Ch-easy model: A cheese-based model to study cheese ripening. Pages 185-190 in Bioflavour 95. P. Étiévant, and P. Schreier, ed. INRA, Dijon, Paris, France.

Tammam, J. D., A. G. Williams, J. Noble, and D. Lloyd. 2000. Amino acid fermentation in non-starter Lactobacillus spp. isolated from Cheddar cheese. Lett. Appl. Microbiol. 30:370-374.

Thomas, T. D. 1987. Cannibalism among bacteria found in cheese N.Z. J. Dairy Sci. Tech. 22:215-219.

Ugarte, M. B., D. Guglielmotti, G. Giraffa, J. Reinheimer, and E. Hynes. 2006. Nonstarter lactobacilli isolated from soft and semihard Argentinean cheeses: Genetic characterization and resistance to biological barriers. J. Food Prot. 69:2983-2991.

Upadhyay, V. K., P. L. H. McSweeney, A. A. A. Magboul, and P. F. Fox. 2004. Proteolysis in cheese during ripening. Pages 391-433 in Cheese: Chemistry, Physics and Microbiology, Vol. 1: General Aspects. P. F. Fox, P. L. H. McSweeney, T. Cogan, and T. Guinee, ed. Academic Press, San Diego, CA

Vélez, M. A., M. C. Perotti, I. V. Wolf, E. R. Hynes, and C. A. Zalazar. 2010. Influence of milk pretreatment on production of free fatty acids and volatile compounds in hard cheeses: Heat treatment and mechanical agitation. J. Dairy Sci. 93:4545-4554.

Williams, A. G., S.-C. Choi, and J. M. Banks. 2002. Variability of the species and strain phenotype composition of the non-starter bacteria population of Cheddar cheese manufactured in a commercial creamery. Food Res. Int. 35:483-493.

Williams, A. G., S. E. Withers, and J. M. Banks. 2000. Energy sources of non-starter lactic acid bacteria isolated from Cheddar cheese. Int. Dairy J. 10:17-23. 